\title{
Analysis of Teacher's Competence about Mathematics Materials for National Final Examination
}

\author{
Syafriandi ${ }^{*}{ }^{1}$, Dina Fitria ${ }^{1}$ \\ ${ }^{1}$ Jurusan Matematika Fakultas Matematika dan Ilmu Pengetahuan Alam Universitas Negeri Padang \\ Jln Prof Dr Hamka Air Tawar Padang, West Sumatera, Indonesia \\ * Correspondence: syafriandi_mat@fmipa.unp.ac.id; Tel.: +62-813-7471-1445
}

Diterima 30 Januari 2018, Disetujui 1 Februari 2018 Dipublikasikan Maret 2018

\begin{abstract}
Principal component in teaching mathematics for teacher is professional competence. It cover how the teacher understand the material of subject matter itself. Teaching Mathematics in Junior High School, teacher have to understand completely in Numbers, Algebra, Geometry and measurements, and also Statistics and probability. Based on the exam and discussion in workshop, known that math teacher in Pesisir Selatan having problems in teaching Geometry and measurement and also Statistics and probability. The problems are complexity of teaching materials, error in translating competence standard and basic competence into lesson plan, time management and student's motivation in studying math. Solution that offered to the teacher are translating basic competence into learning process and trick how to teach Geometry and Statistics especially. Teaching geometry by explain all geometry object, i.e. plane and space simultaneously and compare each object directly. Teaching statistics and probability starting by counting process.
\end{abstract}

Keywords — national final exam, teacher's competencies, geometry, statistics and probability

\section{Pendahuluan}

Kompetensi yang harus dimiliki seorang guru yang diamanahkan [1] mencakup empat aspek, yaitu kompetensi pedagogik, kompetensi professional, kompetensi kepribadian dan kompetensi sosial. Kompetensi professional, berkaitan dengan kemampuan keilmuan. Guru kelas tinggi yaitu guru yang mengajar di kelas VI SD, kelas IX SMP dan kelas XII SMA selalu diberi tantangan mempersiapkan siswa menghadapi Ujian Nasional (UN). Dalam hal ini, para guru dituntut untuk menguasai semua materi yang diajarkan di setiap kelas pada jenjang pendidikan yang mereka ajar. [2]

Berdasarkan analisis hasil [2] Ujian Nasional (UN) tahun 2015/2016 untuk mata pelajaran Matematika, diketahui bahwa kemampuan Matematika siswa SMP Kabupaten Pesisir Selatan masih rendah. Hal ini dapat dilihat dengan memperbandingkannya dengan rata-rata UN Matematika tingkat Provinsi Sumatera Barat ataupun secara Nasional. Selain itu, jika diperhatikan untuk setiap lingkup materi Matematika, meliputi Bilangan, Aljabar, Geometri dan pengukuran, dan Statistik dan peluang diperoleh gambaran yang sama. Hal ini dapat dilihat pada Gambar 1.

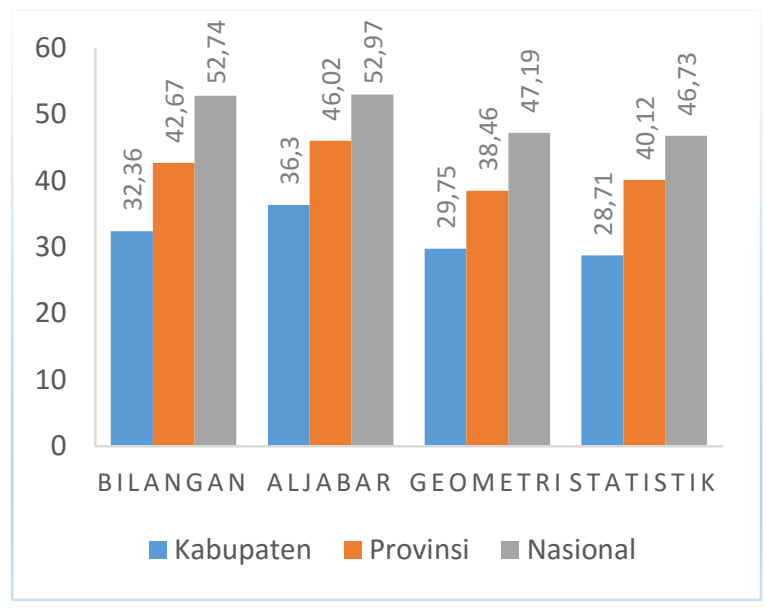

Gambar 1. Hasil UN Matematika SMP Kab Pesisir Selatan Tahun Pelajaran 2015/2016 
Berdasarkan Gambar 1 diketahui bahwa dua lingkup materi Matematika dengan nilai terendah yang diperoleh siswa SMP Kabupaten Pesisir Selatan adalah Geometri dan Pengukuran, dan Statistik dan Peluang. Hal ini menujukkan ada permasalahan dalam pembelajarannya. Berdasarkan analisis ini, dilakukan pelatihan dalam rangka peningkatan kompetensi professional guru dengan fokus utama pada bidang Geometri dan Statistika. Pada umumnya, di negara-negara barat dikenal istilah stokastik sebagai kajian statistika dan peluang. Borovcnik pada [3] menyebutkan bahwa dalam pembelajaran dasar stokastik-statistika dan peluang diperkenalkan tiga ranah, yaitu statistika deskriptif, teori peluang, dan statistika inferensial. [4] statistika deskriptif merupakan pekerjaan mengumpulkan, mengorganisasikan, menyarikan dan menyajikan data. Sedangkan teori peluang berkaitan dengan unsur kebolehjadian. Adapun statistika deskriptif merupakan perumuman dari sampel terhadap populasi, menyajikan estimasi dan hipotesis, menghitung hubungan antar variabel dan membuat prediksi. Pada jenjang SMP, kajian stokastik-statistika dan peluang terbatas pada statistika deskriptif dan teori peluang sederhana. Artikel ini akan membahas mengenai analisis kompetensi professional guru atau disebut kemampuan guru tentang materi yang di-UN-kan.

\section{Solusi/Teknologi}

Kompetensi pedagogik dan profesional guru dapat dilihat dari hasil Ujian Kompetensi Guru (UKG). Namun, karena ada beberapa guru yang belum pernah mengikuti UKG, karena [5] baru tamat dari pendidikan keguruan atau belum terdaftar di dalam Data Pokok Pendidikan, belum memiliki NUPTK, dll, maka diberikan tes pendahuluan (pretest) kepada guru yang mengikuti pelatihan. Soal tes yang diberikan dibuat berdasarkan pemetaan soal UN tahun 2016/2017 yang disesusaikan dengan edaran BSNP tentang kisikisi UN tahun 2017/2018 [6].

Pelatihan dilaksanakan dengan berbagi ide dan solusi (share) dan diskusi. Ditampilkan ringkasan materi yang dipelajari siswa SMP khusus bidang kajian Geometri dan pengukuran, dan Statistik dan peluang. Pada beberapa materi diberikan cara cepat menyelesaikan masalah. Cara cepat yang diberikan merupakan sifat-sifat atau teorema yang biasanya diajarkan pada tingkatan yang lebih tinggi seperti SMA atau perguruan tinggi. Selain itu, guru juga diajak untuk berpikir majemuk atas solusi suatu permasalahan. Selanjutnya dilakukan diskusi bersama guru mengenai materi, baik cara memahami materi ataupun mengembangkan materi tersebut menjadi soal UN.

\section{Hasil dan Diskusi}

Berdasarkan hasil tes, diketahui kemampuan guru Matematika SMP Kab. Pesisir Selatan untuk setiap lingkup materi matematika cukup baik. Hal ini dapat dilihat dari Gambar 2.

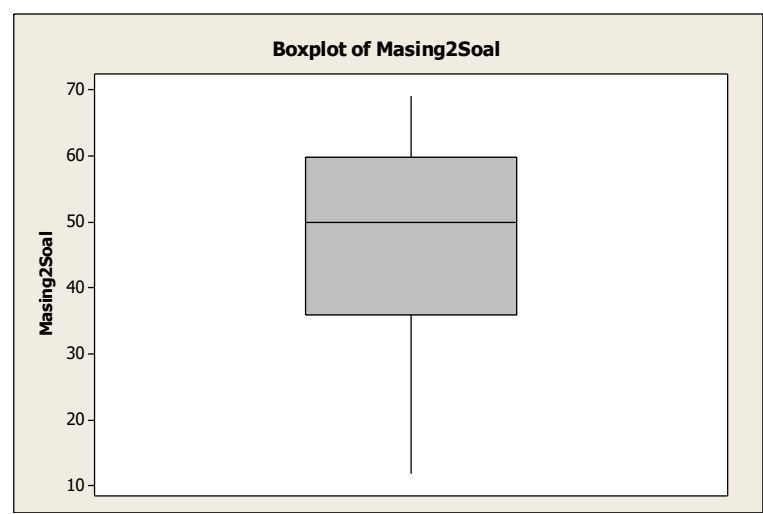

Gambar 2. Hasil Pretes Guru Matematika SMP Kab Pesisir Selatan

Dari 70 guru yang mengikuti ujian dengan 40 butir soal diperoleh bahwa soal tersulit hanya mampu diselesaikan oleh 12 orang guru, sedangkan soal termudah mampu dijawab oleh 69 guru. Adapun soal tersulit itu adalah soal nomor 40, yang kutipan soalnya adalah sebagai berikut.

Dalam kantong berisi 8 kelereng bernomor 1, 2, 3, 4, 5, 6, 7, dan 8. Dua kelereng diambil secara acak. Peluang terambilnya kedua kelereng bernomor genap adalah ...

$\begin{array}{llll}\text { a. } \frac{1}{2} & \text { b. } \frac{4}{21} & \text { c. } \frac{3}{14} & \text { d. } \frac{3}{16}\end{array}$

Rendahnya kuantitas guru yang menjawab soal ini dengan benar disebabkan oleh dua hal. 
Pertama, guru tidak sempat membaca dan menjawab soal ini karena berada pada nomor soal 40. Hal ini menunjukkan buruknya pengaturan waktu yang dilakukan oleh guru. Waktu ujian yang diberikan kepada guru lebih sedikit dibandingkan dengan waktu ujian yang sebenarnya. Menurut teori evaluasi pendidikan, jika guru mampu menyelesaikan soal dalam waktu 1 jam, maka siswa diberi waktu 2 jam untuk menyelesaikannya. Demikian pula, karena UN Matematika harus dikerjakan siswa dalam waktu 2 jam, maka guru hanya diberikan waktu 75 menit untuk menyelesaikan keempat puluh soal. Kedua, guru tidak memahami soal. Kejadian yang dijelaskan soal tidak dipahami guru dengan baik. Berdasarkan hasil diskusi, guru menyatakan bahwa mereka kebingungan ketika menterjemahkan peluang terambil dua kelereng bernomor genap. Mereka ragu, apakah pengambilan dilakukan satu per satu atau pengambilan dilakukan sekaligus. Padahal, jika guru memandang kasus pengambilan satu per satu, tentunya menggunakan peluang bersyarat. Tetapi, jika guru memandang pengambilan dua sekaligus cukup menentukan banyaknya anggota kejadian dan banyaknya anggota ruang sampel dengan cara mencacah semua kemungkinan yang ada. Kedua cara itu menghasilkan jawaban yang sama, yaitu $\frac{3}{14}$.

Selain itu, guru juga terbiasa menghafal cara menyelesaikan soal-soal peluang. Hal ini juga menular kepada siswa yang menghafal cara menjawab suatu soal. Padahal seharusnya mereka memahami soal itu dengan sebaik-baiknya, kemudian menggunakan teori yang telah mereka pelajari untuk menyelesaikan permasalahan itu.

Di lain pihak, soal termudah yaitu soal yang dijawab dengan benar oleh 69 guru adalah soal aljabar dengan tingkatan pengetahuan dan pemahaman. Hal ini bersesuaian dengan teori Bloom bahwa soal dengan ranah $\mathrm{C} 1$ dapat diselesaikan hanya dengan pengetahuan awal yang dimiliki. Selain itu, soal ini disajikan dengan bantuan diagram. Menurut teori gaya belajar [7], pemahaman matematis dapat diterima dengan cepat bagi pemilik gaya belajar visual. Dengan melihat gambar/diagram, mereka memperoleh suatu ide untuk menyelesaikan persoalan yang diberikan. Dan diketahui bahwa sebagian besar pecinta matematika, baik siswa, guru, peneliti dan lainnya merupakan pemiliki gaya belajar visual.

Dilihat dari analisis jawaban setiap guru, diperoleh bahwa skor terendah adalah 8 dan skor tertinggi adalah 38. Guru yang hanya menjawab dengan benar 8 soal adalah guru muda dan yang memperoleh skor tertinggi juga guru muda. Hal ini menunjukkan kualitas masing-masing individu tidak dapat disamakan satu sama lain. Berdasarkan informasi dari peserta pelatihan dan dinas pendidikan terkait, guru yang mendapat skor tertinggi juga merupakan guru yang memperoleh nilai UKG tertinggi di Kabupaten Pesisir Selatan.

Dilihat dari usia, kemampuan guru senior dan guru junior terlihat berbeda. Secara umum, guru senior lebih menguasai materi dan soal-soal UN dibandingkan guru junior. Hal ini disebabkan antara lain oleh faktor pengalaman mengajar. Guru senior telah terbiasa menghadapi masalah yang sama selama bertahun-tahun sehingga mereka sudah hafal dengan tipe-tipe soal dan cara penyelesaian soal yang bersesuaian. Sedangkan guru junior, masih awam dalam menghadapi soalsoal UN. Hal ini senada dengan [8] yang menyatakan bahwa walaupun guru junior pernah mengikuti Program Praktek Lapangan dan telah dinyatakan lulus dengan baik, namun setelah bertugas di sekolah tetap memiliki kelemahan baik dalam persiapan mengajar, cara mengelola kelas, penguasannya terhadap materi pelajaran dan keterampilan lainnya.

Motivasi guru junior dalam memecahkan soal juga terlihat lebih rendah dibanding guru senior. Ketika diberikan suatu soal yang agak sedikit menantang, guru senior bersemangat mencoba menyelesaikannya sebelum instruktur memberikan penyelesaian. Namun, guru junior hanya melihat-lihat soal sambil memupuk harapan agar instruktur segera memberikan penyelesaian tanpa mereka mengukur kemampuannya terlebih dahulu.

Secara umum, kemampuan profesional guru dapat dilihat pada sari numerik yang disajikan pada Tabel 1. 
Tabel 1. Sari Numerik Hasil Pretes Guru

Berdasarkan Skor Individu

\begin{tabular}{|l|c|}
\hline \multicolumn{1}{|c|}{ Statistik } & Nilai \\
\hline Banyak peserta & 70 \\
\hline Nilai minimum & 8 \\
\hline Kuartil 1 & 22,75 \\
\hline Median & 27 \\
\hline Kuartil 3 & 33 \\
\hline Nilai maksimum & 38 \\
\hline Rata-rata & 26,6 \\
\hline Modus & 34 \\
\hline Standar deviasi & 7,18 \\
\hline
\end{tabular}

Berdasarkan Tabel 1, guru hanya mampu menjawab dengan rata-rata 26,6 atau sekitar 27 soal dengan benar dan standar deviasi 7,18. Hal ini menujukkan bahwa guru mampu menyelesaikan lebih dari separuh soal dan masing-masing guru memiliki perbedaan sebesar 7,18. Nilai ini masih besar, artinya kemampuan masing-masing guru berbeda jauh. Ada guru yang terlalu cepat/pintar/teliti dan ada guru yang lambat. Namun, dilihat dari statistik lima serangkai yaitu nilai minimum, nilai maksimum, kuartil 1, kuartil 2, dan kuartil 3 diketahui bahwa kemampuan guru tersebar lebih condong ke arah nilai besar. Hal ini memberi makna bahwa banyak guru yang memperoleh nilai antara kuartil 1 dan kuartil 2, lebih sedikit dibandingkan banyak guru yang memperoleh nilai antara kuartil 2 dan kuartil 3. Tentunya menunjukkan semakin banyak soal yang dijawab benar oleh guru-guru. Hal ini juga didukung dengan nilai modus yang merupakan nilai dengan frekuensi terbesar [9] yaitu 34 .

Dilihat dari lingkup materi, kompetensi professional guru matematika SMP se Kab. Pesisir Selatan disajikan pada Gambar 3.

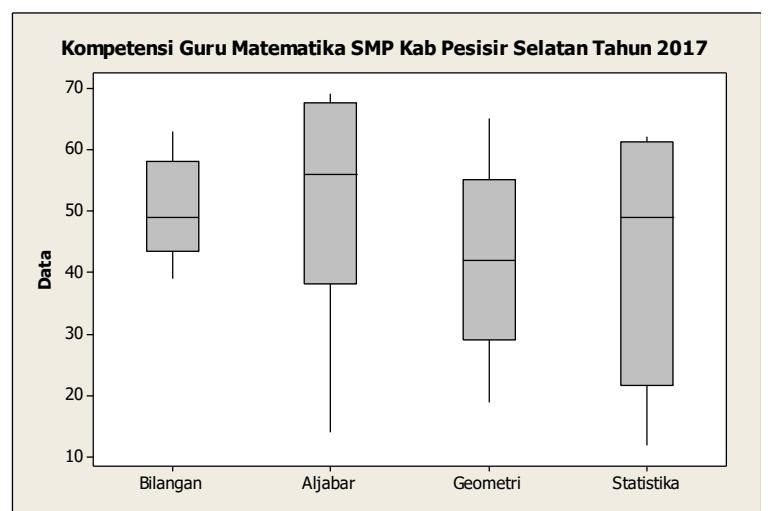

Gambar 3. Hasil Pretes Guru Matematika SMP Kab Pesisir Selatan Berdasarkan Lingkup Materi Matematika
Lingkup materi Matematika SMP yang ditetapkan pemerintah yang tertuang dalam [10] meliputi Bilangan, Aljabar, Geometri dan pengukuran, dan Statistika dan Peluang. Materi ini juga memiliki konten yang serupa dengan materi yang dituangkan dalam NCTM [11], yaitu Bilangan dan operasinya, Aljabar, Geometri, Pengukuran, Analisis data dan peluang, Pemecahan masalah, Penalaran dan pembuktian, Komunikasi, Koneksi, dan Representasi.

Pada soal pretest diberikan 9 soal Bilangan, 10 soal Aljabar, 15 soal Geometri dan pengukuran dan 6 soal Statistika dan peluang. Berdasarkan diagram kotak-garis (boxplot) yang disajikan pada Gambar 3 terlihat bahwa kemampuan guru cukup rendah pada bidang Geometri dan Statistika. Hal ini senada dengan kemampuan siswa yang disajikan pada Gambar 1 . Garis tengah pada boxplot menunjukkan nilai median dari data dan lebar kotak menunjukkan range atau selisih datum terkecil dengan datum terbesar. Adapun sari numerik kemampuan guru untuk setiap lingkup materi ini dapat dilihat pada Tabel 2.

Tabel 2. Sari Numerik Hasil Pretes Guru Berdasarkan Lingkup Materi

\begin{tabular}{|l|c|c|c|c|}
\hline \multicolumn{1}{|c|}{ Statistik } & Bilangan & Aljabar & Geometri & Statistik \\
\hline $\begin{array}{l}\text { Banyak } \\
\text { soal }\end{array}$ & 9 & 11 & 14 & 6 \\
\hline $\begin{array}{l}\text { Nilai } \\
\text { minimum }\end{array}$ & 39 & 14 & 19 & 12 \\
\hline Kuartil 1 & 46,5 & 42 & 28,5 & 21,75 \\
\hline Median & 50 & 54 & 39 & 49 \\
\hline Kuartil 3 & 60,5 & 67 & 52,75 & 61,25 \\
\hline $\begin{array}{l}\text { Nilai } \\
\text { maksimum }\end{array}$ & 63 & 69 & 65 & 62 \\
\hline Rata-rata & 52,11 & 50,73 & 41,21 & 43 \\
\hline Modus & - & 42 & 36 & - \\
\hline $\begin{array}{l}\text { Standar } \\
\text { deviasi }\end{array}$ & 8,07 & 18,07 & 14,64 & 20,37 \\
\hline
\end{tabular}

Boxplot Bilangan terlihat kecil dan padat. Artinya, kemampuan guru terhadap materi Bilangan cukup baik dengan rataan 52,11 dan standar deviasi 8,07. Sedangkan untuk Aljabar, terlihat kotak yang lebar dengan ekor bawah yang panjang. Ini memberikan makna bahwa kemampuan Aljabar guru sangat bervariasi, yang dibuktikan pula dengan standar deviasi yang cukup besar yaitu 18,07 dan masih banyak 
diantara guru tersebut yang memiliki kemampuan Aljabar yang rendah. Pada materi Geometri, terlihat bahwa ekor atas dan ekor bawah boxplot agak seimbang, namun rataannya lebih rendah dibanding materi lainnya. Demikian pula untuk materi Statistika. Tampak bahwa ekor bawah boxplot lebih panjang dan kotak terbagi menjadi dua bagian, yang mana bagian bawahnya lebih panjang. Artinya, nilai yang diperoleh guru lebih banyak pada skor kecil dibandingkan skor yang lebih besar. Secara garis besar, Gambar 3 dan Tabel 2 menjelaskan bahwa kemampuan guru tidak berbeda jauh dengan kemampuan siswa yang disajikan pada Gambar 1. Siswa bermasalah/mengalami kesulitan pada materi Geometri dan Statistika, dan ternyata guru juga bermasalah pada materi yang sama.

Selain itu, dilihat dari kompetensi guru terhadap masing-masing tingkatan soal, yaitu Pengetahuan dan Pemahaman, Aplikasi dan Penalaran diperoleh gambaran seperti pada Gambar 4 dan Tabel 3.

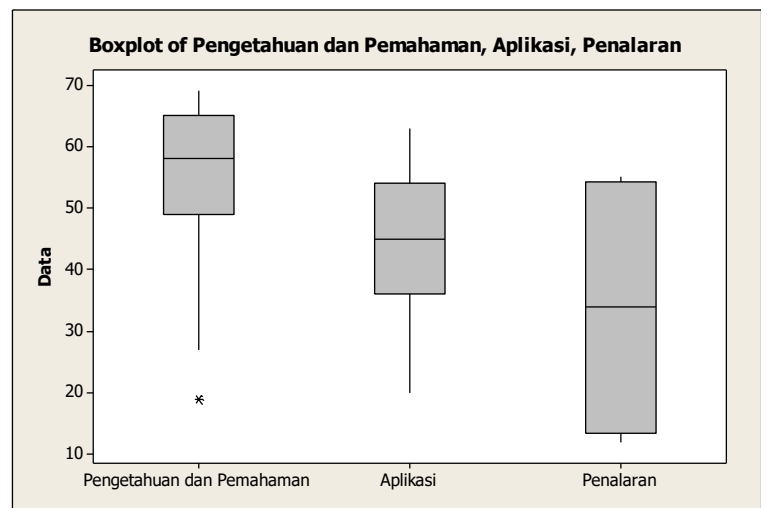

Gambar 4. Hasil Pretes Guru Matematika SMP Kab Pesisir Selatan Berdasarkan Tingkatan Soal

Terlihat bahwa terdapat suatu hal menarik pada boxplot Pengetahuan dan Pemahaman, yaitu adanya pencilan (outlier). Pencilan merupakan data yang memiliki nilai terlalu besar dibandingkan data lainnya jika terletak di bagian atas dan disebut pencilan atas, atau disebut pencilan bawah jika memiliki nilai yang terlalu kecil dibandingkan data lainnya jika terletak di bagian bawah.
Tabel 3. Sari Numerik Hasil Pretes Guru Berdasarkan Tingkatan Soal

\begin{tabular}{|l|c|c|c|}
\hline \multicolumn{1}{|c|}{ Statistik } & $\begin{array}{c}\text { Pengetahuan dan } \\
\text { Pemahaman }\end{array}$ & Aplikasi & Penalaran \\
\hline $\begin{array}{l}\text { Banyak } \\
\text { soal }\end{array}$ & 15 & 19 & 6 \\
\hline $\begin{array}{l}\text { Nilai } \\
\text { minimum }\end{array}$ & 19 & 20 & 12 \\
\hline Kuartil 1 & 49 & 36 & 13,5 \\
\hline Median & 58 & 45 & 34 \\
\hline Kuartil 3 & 65 & 54 & 54,25 \\
\hline $\begin{array}{l}\text { Nilai } \\
\text { maksimum }\end{array}$ & 69 & 63 & 55 \\
\hline Rata-rata & 53,27 & 45,26 & 33,83 \\
\hline Modus & 69 & 42 & - \\
\hline $\begin{array}{l}\text { Standar } \\
\text { deviasi }\end{array}$ & 8,07 & 18,07 & 14,64 \\
\hline
\end{tabular}

Pencilan data yang terdeteksi adalah soal yang hanya mampu dijawab dengan benar oleh 19 guru yaitu soal yang kutipannya sebagai berikut.

Diketahui segitiga-segitiga dengan panjang sisi-sisi sebagai berikut.

(1) $3 \mathrm{~cm}, 4 \mathrm{~cm}$, dan $6 \mathrm{~cm}$

(2) $10 \mathrm{~cm}, 15 \mathrm{~cm}$ dan $20 \mathrm{~cm}$

(3) $10 \mathrm{~cm}, 13 \mathrm{~cm}$ dan $15 \mathrm{~cm}$

(4) $15 \mathrm{~cm}, 25 \mathrm{~cm}$ dan $15 \mathrm{~cm}$

Yang merupakan segitiga lancip adalah ...
a. (1)
b. (2)
c. (3)
d. (4)

Dilihat dari kelompok materinya, soal ini merupakan kelompok soal Geometri. Sebagaimana yang telah dijelaskan oleh Gambar 3 dan Tabel 2, Geometri merupakan salah satu materi sulit bagi guru. Dilihat dari waktu pembelajarannya, soal di atas berkaitan dengan materi yang dipelajari siswa pada kelas VII sehingga sudah banyak diantara guru yang lupa bahkan ada diantaranya yang mengatakan tidak mengetahui konsep pembentukan segitiga lancip. Hal ini menunjang asumsi penulis bahwa pelajaran matematika di sekolah didominasi oleh kalkulasi tanpa pemaknaan. Soal ini selaras dengan soal yang menayakan kriteria yang harus dipenuhi sisi-sisi agar dapat membentuk sebuah segitiga. Guru hendaknya memperbanyak praktikum pada pelajaran matematika sehingga lebih bermakna. Secara umum, soal Pengetahuan dan Pemahaman merupakan soal dengan kategori mudah. Rata-rata 53,27 atau sekitar 54 guru menjawab soal Pengetahuan dan Pemahaman dengan benar, dengan standar deviasi 15,47. 
Perbedaan jawaban benar antar soal masih cukup besar yang menunjukkan keberagaman kemampuan guru. Namun, untuk soal Pengetahuan dan Pemahaman dapat dipastikan bahwa tingginya keberagaman ini disebabkan oleh faktor kecepatan guru dalam menyelesaikan soal disamping faktor lupa.

Pada soal Aplikasi, data menyebar cukup simetris. Diperoleh rata-rata 45,26 dan standar deviasi 12,44 dengan range 43. Hal ini menunjukkan sebaran yang cukup baik atau merata antar kemampuan para guru dalam menyelesaikan soal aplikasi.

Pada soal Penalaran, terlihat bahwa kemampuan penalaran guru juga tergolong rendah. Hal ini ditunjukkan oleh rataan sebesar 33,83 dengan standar deviasi 18,84. Adapun soal tersulit yang hanya dijawab dengan benar oleh 12 orang guru dan soal penalaran termudah mampu dijawab dengan benar oleh 55 orang guru. Beberapa penyebab rendahnya kemampuan penalaran ini adalah masalah waktu dan prioritas dalam menjawab soal. Jika merujuk hasil TIMSS 2015, kemampuan penalaran siswa dan guru yang diujikan juga lebih rendah dibandingkan dengan kemampuan bidang lainnya.

Pada diskusi yang dilaksanakan selama pelatihan, diketahui pula bahwa dalam pembelajaran terkait materi Geometri dan pengukuran, guru menterjemahkan KD mengenai bangun datar dan bangun ruang dengan mengajarkan masing-masing bangun secara detail dan terpisah. Artinya materi kubus, diajarkan dengan memperkenalkan kubus, jaring-jaring kubus, menghitung luas permukaan dan volume kubus serta menggunakannya dalam pemecahan masalah. Demikian pula untuk balok, prisma, limas dan bangun lainnya. Hal ini menyebabkan siswa tidak mampu menghubungkan bangunbangun itu satu sama lain. Padahal, dengan KD yang ada, memperkenalkan bangun ruang, siswa mengenali karakteristik yang sama antar bangunbangun ruang itu. Mereka akan dapat membuat suatu kesimpulan bahwa kubus, balok dan prisma memiliki karakteristik yang sama. Menghitung luas permukaan dan volumenya juga sama. Ketiga bangun itu adalah prisma, namun untuk kubus, semua sisi prismanya adalah persegi yang berukuran sama, sedangkan untuk balok, ada tiga pasang persegi kongruen. Akan tetapi ketiganya adalah prisma. Demikian pula bangun ruang lainnya. Dalam menghitung volume, semua bangun ruang memiliki volume yang nilainya adalah luas alas dikali tinggi. Namun, bangun ruang yang memiliki puncak, volumenya sepertiga dari luas alas dikali tinggi.

Pada materi Statistika dan Peluang, guru terbiasa menjelaskan materi dengan metode menghafal. Guru dan siswa kesulitan memahami kasus-kasus peluang, khususnya. Guru disarankan menggunakan prinsip dasar menghitung yang dimulai dengan mencacah semua kondisi yang mungkin dipenuhi oleh kejadian yang diberikan. Kemudian, guru diminta menggunakan konsep dasar peluang, bahwa peluang suatu kejadian adalah banyaknya kejadian yang teramati dibandingkan dengan banyaknya anggota ruang sampel.

\section{Kesimpulan}

Kompetensi professional guru Matematika SMP se-Kabupaten Pesisir Selatan beragam. Diperlukan peningkatan kompetensi, terutama guru junior dengan pelatihan sejenis atau tutor sejawat dan dilaksanakan secara rutin.

\section{Ucapan Terima Kasih}

Penulis mengucapkan terimakasih kepada Dinas Pendidikan Kabupaten Pesisir Selatan yang telah memfasilitasi kegiatan pelatihan peningkatan kompetensi guru.

\section{Pustaka}

[1] Undang-undang No 14 Tahun 2005 tentang Guru dan Dosen

[2] Dinas Pendidikan Sumatera Barat. Hasil Ujian Nasional Tahun Pelajaran 2015/2016

[3] Garfield, Joan and Andrew Ahlgren.1988. Difficulties in Learning Basic Concepts in Probability and Statistics: Implication for Research. Journal for Research in 
Mathematics Education Vol. 19 No 1. pp. 4463

[4] Bluman. 2009. Elementary Statistics: A Step By Step Approach, Eighth Edition. McGrawHill

[5] Direktorat Jendral Guru dan Tenaga Kependidikan. 2015. Pedoman Pelaksanaan Uji Kompetensi Guru. Kementrian Pendidikan dan Kebudayaan

[6] BSNP. Kisi-kisi USBN dan UN Tahun Pelajaran 2017/2018
[7] De Porter, Bobby and Mike Hernacki. 2001. Quantum Learning: Membiasakan Belajar Nyaman dan Menyenangkan. Penerbit Kaifa

[8] A. Hasan Saragih. 2008. Kompetensi Minimal Seorang Guru dalam Mengajar. Jurnal Tabularasa PPs Unimed; 23-34

[9] Freund, R.J and William J. Wilson. Statistical Method $2^{\text {nd }}$ Edition: Academic Press

[10] Permendikbud No 21 Tahun 2016 tentang Standar Isi Pendidikan Dasar dan Menengah 